\title{
PARENTAL KNOWLEDGE, ATTITUDES AND PRACTICES (KAPS) ON THE USE OF ANTIBIOTICS IN CHILDREN FOR UPPER RESPIRATORY TRACT INFECTIONS (URTIS)
}

\author{
NORAIDA MOHAMED SHAH*, MASTURA ABDUL RAHIM \\ Faculty of Pharmacy, Universiti Kebangsaan Malaysia, Jalan Raja Muda Abdul Aziz, 50300 Kuala Lumpur, Malaysia \\ Email: noraida_mshah@ukm.edu.my
}

Received: 14 Oct 2016 Revised and Accepted: 17 Jan 2017

\begin{abstract}
Objective: This study aimed to assess the knowledge, attitudes and practices (KAPs) of parents on the use of antibiotics among children for upper respiratory tract infections (URTIs).

Methods: This cross-sectional study was conducted from September to November 2014 at kindergartens around Kuala Lumpur. Data were collected using questionnaires which were distributed to parents with children aged $\leq 6 \mathrm{y}$.

Results: A total of 169 parents participated in this study. Parental knowledge on the use of antibiotics in children for URTI was poor with a mean score of 1.99+1.27 (total score = 5). The overall attitude was positive with a mean score of 23.01+6.17 (total score $=60$ ). Gender, educational level, personal and household monthly incomes were significantly associated with both knowledge and attitudes (a total score of $p<0.05$ ). A moderate, significant negative correlation was found between knowledge score and attitude score $\left(r_{s}=-0.498, p<0.001\right)$.
\end{abstract}

Conclusion: This study provides an insight towards parental KAPs on the use of antibiotics among children for URTIs. Improving parental KAPs may reduce the inappropriate use of antibiotics among children.

Keywords: Knowledge, Attitudes, Practices, Children, Upper Respiratory Tract Infections

(C) 2016 The Authors. Published by Innovare Academic Sciences Pvt Ltd. This is an open access article under the CC BY license (http://creativecommons.org/licenses/by/4. 0/)

DOI: http://dx.doi.org/10.22159/ijpps.2017v9i3.15674

\section{INTRODUCTION}

Children are more prone to get upper respiratory tract infections (URTIs) compared to adults due to their immature immune response against viruses. Thus, it is common for children to get URTIs up to ten times per year, and the frequency increases when a child starts to mix with a large number of other children at a nursery or school [1]. In most cases, antibiotics are not required as most URTIs are caused by viruses [2]. As respiratory tract infections in children are self-limiting with very minimal risk of complications, their management typically involves self-care and symptomatic treatments [3].

Van de Sande-Bruinsma et al. reported that the prevalence of pathogen resistance is the highest in countries that have a high consumption of antibiotics [4]. The misuse of antibiotics for URTIs among children has become a major contributor to the emergence of antibiotic resistance [5]. Inappropriate use of antibiotics in URTIs can also lead to healthcare resource wastage and adverse effects [6]. One of the reasons most doctors prescribed antibiotics for viral URTIs in children is to fulfill parents' expectations for such treatment [7]. There are limited studies reported in Malaysia on parental knowledge, attitudes and practices KAPs regarding the use of antibiotics in children for URTIs [8]. In the present research, sociodemographic factors that may influence the KAPs on the use of antibiotics in children were also investigated as the main objective of the research.

\section{MATERIALS AND METHODS}

\section{Study design}

This study was performed as a cross-sectional survey from September to November 2014. The study was approved by the Research Committee of Faculty of Pharmacy and the Research Ethics Committee of Universiti Kebangsaan Malaysia (UKM) (UKM 1.5.3.5/244/NF-021-14). The questionnaires were distributed to kindergartens in Kuala Lumpur. The list of kindergartens was obtained from an online network source [9] and permission to conduct the study was sought from the kindergartens' managers prior to the commencement of the study. Questionnaires were distributed by the teachers to the parents. Parents who could understand either the Malay or English language with at least a child aged $\leq 6 \mathrm{y}$ old during the study period were invited to take part in the research.

Knowledge, attitude and practice questionnaire

The questionnaire was adapted from a previous study, with permission from its author, to suit the local population [10]. It was designed to include four parts: Demographic data (Part A), Knowledge (Part B), Attitudes (Part C) and Practices (Part D) of parents on the use of antibiotics in children for URTIs. The questions are found in tables 2,4 and 6.

\section{Data analyses}

The Statistical Package for Social Science (SPSS ${ }^{\circledR}$ Version 22; IBM Armonk, NY, USA) was utilized to analyze the data. Mann-Whitney U or Kruskal-Wallis test was used to make a comparison and evaluate possible associations regarding parental knowledge, attitudes and practices. Spearman's rank order correlation $\left(r_{s}\right)$ was used to analyze the relationship between total scores of knowledge and attitudes. The level of statistical significance was defined as $p$ value less than $0.05(p<0.05)$.

\section{RESULTS}

Over a period of two months, 47 kindergartens were approached. Eighteen out of the total 47 kindergartens were interested in participating in the study. For these kindergartens, 651 questionnaires were distributed to the parents by the teachers. At the end of data collection week, a total of 310 sets of questionnaires were successfully collected. However, only 169 sets could be used for further analysis. The remaining sets were excluded due to incomplete data.

\section{Demographic data}

More than half of the respondents were female (66.3\%), aged between 30 and $39(63.3 \%)$ and were of the Malay ethnicity 
(86.4\%). The majority of the participants were married (96.4\%). A total of $60.4 \%$ of the participants were graduates from tertiary education institutions and more than half were salaried employees (79.9\%). The complete demographic profile of the study sample is shown in table 1.

Table 1: Demographic data $(n=169)$

\begin{tabular}{|c|c|c|}
\hline Demographic characteristics & & Number of respondents, n (\%) \\
\hline \multirow[t]{2}{*}{ Gender } & Male & $57(33.7)$ \\
\hline & Female & $112(66.3)$ \\
\hline \multirow[t]{4}{*}{ Age (years) } & $21-29$ & $16(9.5)$ \\
\hline & $30-39$ & $107(63.3)$ \\
\hline & $40-49$ & $45(26.6)$ \\
\hline & $\geq 50$ & $1(0.6)$ \\
\hline \multirow[t]{4}{*}{ Ethnicity } & Malay & $146(86.4)$ \\
\hline & Chinese & $19(11.2)$ \\
\hline & Indian & $1(0.6)$ \\
\hline & Others & $3(1.8)$ \\
\hline \multirow[t]{3}{*}{ Marital status } & Married & $163(96.4)$ \\
\hline & Widow & $2(1.2)$ \\
\hline & Divorced & $4(2.4)$ \\
\hline \multirow[t]{4}{*}{ Educational level } & No formal education & $2(1.2)$ \\
\hline & Primary & $1(0.6)$ \\
\hline & Secondary & $64(37.9)$ \\
\hline & Tertiary & $102(60.4)$ \\
\hline \multirow[t]{4}{*}{ Occupation } & Student & $1(0.6)$ \\
\hline & Housewife & $16(9.5)$ \\
\hline & Self-employed & $17(10.1)$ \\
\hline & Salaried employee & $135(79.9)$ \\
\hline \multirow[t]{6}{*}{ Personal monthly income } & 0 & $11(6.5)$ \\
\hline & $<$ RM 1000 & $5(3.0)$ \\
\hline & RM 1000-RM 2000 & $21(12.4)$ \\
\hline & RM 2000-RM 3000 & $42(24.9)$ \\
\hline & RM 3000-RM 4000 & $42(24.9)$ \\
\hline & $>\mathrm{RM} 4000$ & $48(28.4)$ \\
\hline \multirow[t]{6}{*}{ Household monthly income } & 0 & $0(0)$ \\
\hline & $<$ RM 1000 & $6(3.6)$ \\
\hline & RM 1000-RM 2000 & $5(3.0)$ \\
\hline & RM 2000-RM 3000 & $20(11.8)$ \\
\hline & RM 3000-RM 4000 & $41(24.3)$ \\
\hline & $>$ RM 4000 & $97(57.4)$ \\
\hline \multirow[t]{5}{*}{ Number of children } & 1 & $18(10.7)$ \\
\hline & 2 & $55(32.5)$ \\
\hline & 3 & $52(30.8)$ \\
\hline & 4 & $27(16.0)$ \\
\hline & $\geq 5$ & $17(10.1)$ \\
\hline
\end{tabular}

\section{Parental knowledge on antibiotic use in children with URTIs}

The total score in the knowledge section was computed as the number of correct responses to the questions (range 0-5). Twothirds of the parents had poor knowledge on the use of antibiotics in children for URTIs (total score 0-2).

The overall mean+SD of the respondents' knowledge was 1.99+1.27. Out of the five questions, only two questions were answered correctly by more than half of the respondents, indicating poor knowledge on the use of antibiotics in children with URTIs.
Only $31.4 \%$ of the parents believed URTIs are of viral origin and do not require antibiotics to resolve the infection. Although $69.2 \%$ of the parents acknowledged that inappropriate use of antibiotic leads to bacterial resistance, more than half of the parents $(53.8 \%)$ believed that flu-like symptoms resolved faster when antibiotics were given

Table 2 shows the results of parental knowledge on the use of antibiotics for URTIs in children. There was a significant association between the total knowledge score and gender, educational level as well as both personal and household monthly incomes (table 3).

Table 2: Parental knowledge on the use of antibiotics in children for URTIs $(n=169)$

\begin{tabular}{|c|c|c|c|}
\hline \multirow[t]{2}{*}{ Statements } & \multicolumn{3}{|c|}{ Number of respondents, $\mathrm{n}(\%)$} \\
\hline & Yes & No & Not sure \\
\hline The antibiotic should be given to all children who develop a fever. & $58(34.3)$ & $100(59.2)^{*}$ & $11(6.5)$ \\
\hline $\begin{array}{l}\text { As most of the Upper Respiratory Tract Infections (e. g. cold, flu, sore throat, ear infection) are of } \\
\text { viral origin, antibiotics should not be given because they are self-limited. }\end{array}$ & $53(31.4)^{*}$ & $84(49.7)$ & 32 (18.9) \\
\hline Children with flu-like symptoms get better faster when antibiotics are given. & $91(53.8)$ & $48(28.4)^{*}$ & $30(17.8)$ \\
\hline Inappropriate use of antibiotics reduces their efficacy and leads to bacterial resistance. & $117(69.2)^{*}$ & $21(12.4)$ & $31(18.3)$ \\
\hline Antibiotic use can prevent complications from Upper Respiratory Tract Infections. & $100(59.2)$ & $18(10.7)^{*}$ & $51(30.2)$ \\
\hline
\end{tabular}

*Number of respondents who answered the question correctly. 
Table 3: Association between knowledge score and demographic data $(n=169)$

\begin{tabular}{|c|c|c|c|}
\hline Variable & & Mean+SD knowledge score & p-value \\
\hline \multirow[t]{2}{*}{ Gender $^{\mathrm{a}}$} & Male & $1.61+1.26$ & $0.007^{*}$ \\
\hline & Female & $2.18+1.23$ & \\
\hline \multirow[t]{4}{*}{ Age (years) ${ }^{b}$} & $21-29$ & $1.81+1.38$ & 0.354 \\
\hline & $30-39$ & $1.92+1.21$ & \\
\hline & $40-49$ & $2.24+1.35$ & \\
\hline & $\geq 50$ & $1.00+0.00$ & \\
\hline \multirow[t]{4}{*}{ Ethnicity b } & Malay & $1.91+1.28$ & 0.165 \\
\hline & Chinese & $2.58+1.07$ & \\
\hline & Indian & $2.00+0.00$ & \\
\hline & Others & $2.00+1.73$ & \\
\hline \multirow[t]{3}{*}{ Marital status ${ }^{b}$} & Married & $2.00+1.28$ & 0.821 \\
\hline & Widow & $1.50+0.71$ & \\
\hline & Divorced & $1.75+1.26$ & \\
\hline \multirow[t]{4}{*}{ Educational level ${ }^{\mathrm{b}}$} & No formal education & $1.50+0.71$ & $0.004^{*}$ \\
\hline & Primary & $1.00+0.00$ & \\
\hline & Secondary & $1.59+1.26$ & \\
\hline & Tertiary & $2.25+1.22$ & \\
\hline \multirow[t]{5}{*}{ Occupation ${ }^{\mathrm{b}}$} & Unemployed & $0.00+0.00$ & 0.131 \\
\hline & Student & $3.00+0.00$ & \\
\hline & Housewife & $1.50+1.03$ & \\
\hline & Self-employed & $1.59+1.37$ & \\
\hline & Salaried employee & $2.09+1.27$ & \\
\hline \multirow[t]{6}{*}{ Personal monthly income b } & 0 & $1.64+1.12$ & $0.001^{*}$ \\
\hline & $<$ RM 1000 & $1.40+0.55$ & \\
\hline & RM 1000-RM 2000 & $1.48+1.03$ & \\
\hline & RM 2000-RM 3000 & $1.64+1.30$ & \\
\hline & RM 3000-RM 4000 & $2.05+1.23$ & \\
\hline & $>$ RM 4000 & $2.60+1.23$ & \\
\hline \multirow[t]{6}{*}{ Household monthly income ${ }^{b}$} & 0 & $0.00+0.00$ & $0.000^{*}$ \\
\hline & $<$ RM 1000 & $2.00+1.10$ & \\
\hline & RM 1000-RM 2000 & $0.80+0.84$ & \\
\hline & RM 2000-RM 3000 & $1.40+1.14$ & \\
\hline & RM 3000-RM 4000 & $1.59+1.16$ & \\
\hline & $>$ RM 4000 & $2.34+1.25$ & \\
\hline \multirow[t]{5}{*}{ Number of children ${ }^{b}$} & 1 & $1.94+1.77$ & \\
\hline & 2 & $1.87+1.17$ & 0.813 \\
\hline & 3 & $1.98+1.32$ & \\
\hline & 4 & $2.15+0.82$ & \\
\hline & $\geq 5$ & $2.18+1.47$ & \\
\hline
\end{tabular}

Values were expressed as mean \pm standard deviation, * Indicates a significant difference at $p<0.05$, a Mann-Whitney test; ${ }^{\circ}$ Kruskal-Wallis test

Table 4: Parental attitudes on the use of antibiotics in children for URTIs ( $n=169$ )

\begin{tabular}{|c|c|c|c|c|c|}
\hline & \multicolumn{5}{|c|}{ Number of respondents, $\mathrm{n}(\%)$} \\
\hline & Never & Sometimes & Often & $\begin{array}{l}\text { Most of } \\
\text { the times }\end{array}$ & Always \\
\hline \multicolumn{6}{|l|}{$\begin{array}{l}\text { Q20. How often would you give your child antibiotics without the medical } \\
\text { doctor's advice, for the following reasons? }\end{array}$} \\
\hline Because you did not have enough spare time to visit a medical doctor. & $136(80.5)$ & $24(14.2)$ & $3(1.8)$ & $3(1.8)$ & $3(1.8)$ \\
\hline Because you did not have enough money to pay for the visit. & $152(89.9)$ & $12(7.1)$ & $2(1.2)$ & $1(0.6)$ & $2(1.2)$ \\
\hline Because you thought that your child's condition was not serious enough. & $108(63.9)$ & $38(22.5)$ & $11(6.5)$ & $6(3.6)$ & $6(3.6)$ \\
\hline $\begin{array}{l}\text { Because your medical doctor had prescribed the same antibiotic in the past for } \\
\text { the same symptoms. }\end{array}$ & $108(63.9)$ & $33(19.5)$ & $18(10.7)$ & $5(3.0)$ & $5(3.0)$ \\
\hline Because a pharmacist recommended the antibiotic. & $104(61.5)$ & $31(18.3)$ & $19(11.2)$ & $6(3.6)$ & $9(5.3)$ \\
\hline Because a friend/family relative recommended the antibiotic. & $130(76.9)$ & $24(14.2)$ & $9(5.3)$ & $3(1.8)$ & $3(1.8)$ \\
\hline $\begin{array}{l}\text { Q21. Would you change your medical doctor for not prescribing as many } \\
\text { antibiotics as you think he/she should? }\end{array}$ & $58(34.3)$ & $44(26.0)$ & $28(16.6)$ & $28(16.6)$ & $11(6.5)$ \\
\hline $\begin{array}{l}\text { Q22. Would you reuse any leftover antibiotics whenever your child presents } \\
\text { similar symptoms of an Upper Respiratory Tract Infections (i.e. a sore throat, } \\
\text { flu, cold)? }\end{array}$ & $126(74.6)$ & $25(14.8)$ & $2(1.2)$ & $13(7.7)$ & $3(1.8)$ \\
\hline $\begin{array}{l}\text { Q23. Do you think that parents and medical doctors should be informed about } \\
\text { judicious antibiotic use? }\end{array}$ & $2(1.2)$ & $4(2.4)$ & $0(0)$ & $32(18.9)$ & $\begin{array}{l}131 \\
(77.5)\end{array}$ \\
\hline $\begin{array}{l}\text { Q24. Do you think that most of the Upper Respiratory Tract Infections (i.e. flu, } \\
\text { cold, ear infection) resolve without the administration of an antibiotic because } \\
\text { they are self-limited? }\end{array}$ & $20(11.8)$ & 33 (19.5) & $58(34.3)$ & $42(24.9)$ & $16(9.5)$ \\
\hline $\begin{array}{l}\text { Q25. Would you request for an antibiotic prescription if your child suffers from } \\
\text { frequent Upper Respiratory Tract Infections? }\end{array}$ & $15(8.9)$ & $35(20.7)$ & $43(25.4)$ & $58(34.3)$ & $18(10.7)$ \\
\hline Q26. Would you visit a medical doctor if your child suffers just from a runny nose? & $29(17.2)$ & $42(24.9)$ & $23(13.6)$ & $62(36.7)$ & $13(7.7)$ \\
\hline
\end{tabular}

There was no significant difference with regards to age, ethnicity, marital status, occupation and number of children with the total attitude score. However, there was a significant association between gender, educational level, personal and household monthly incomes and the total attitude score $(p<0.05$, table 5$)$. 
Table 5: Association between attitude score and demographic data $(n=169)$

\begin{tabular}{|c|c|c|c|}
\hline Variable & & Mean+SD attitude score & $p$-value \\
\hline \multirow[t]{2}{*}{ Gender a } & Male & $24.40+5.38$ & $0.004^{*}$ \\
\hline & Female & $22.29+6.44$ & \\
\hline \multirow[t]{4}{*}{ Age (years) b } & $21-29$ & $22.25+5.64$ & 0.898 \\
\hline & $30-39$ & $23.25+6.24$ & \\
\hline & $40-49$ & $22.76+6.33$ & \\
\hline & $\geq 50$ & $20.00+0.00$ & \\
\hline \multirow[t]{4}{*}{ Ethnicity b } & Malay & $23.24+6.26$ & 0.311 \\
\hline & Chinese & $20.68+3.53$ & \\
\hline & Indian & $22.00+0.00$ & \\
\hline & Others & $26.67+12.90$ & \\
\hline \multirow[t]{3}{*}{ Marital status ${ }^{b}$} & Married & $22.87+6.10$ & 0.257 \\
\hline & Widow & $32.00+12.73$ & \\
\hline & Divorced & $24.00+2.94$ & \\
\hline \multirow[t]{4}{*}{ Educational level b } & No formal education & $30.50+14.85$ & $0.006^{*}$ \\
\hline & Primary & $28.00+0.00$ & \\
\hline & Secondary & $24.78+6.70$ & \\
\hline & Tertiary & $21.70+5.29$ & \\
\hline \multirow[t]{5}{*}{ Occupation ${ }^{b}$} & Unemployed & $0.000+0.00$ & 0.092 \\
\hline & Student & $19.00+0.00$ & \\
\hline & Housewife & $25.25+6.95$ & \\
\hline & Self-employed & $25.59+7.02$ & \\
\hline & Salaried employee & $22.44+5.88$ & \\
\hline \multirow[t]{6}{*}{ Personal monthly income ${ }^{b}$} & 0 & $24.82+7.87$ & $0.014^{*}$ \\
\hline & $<$ RM 1000 & $27.20+8.04$ & \\
\hline & RM 1000-RM 2000 & $24.95+5.84$ & \\
\hline & RM 2000-RM 3000 & $23.81+6.05$ & \\
\hline & RM 3000-RM 4000 & $22.12+4.60$ & \\
\hline & $>$ RM 4000 & $21.38+6.64$ & \\
\hline \multirow[t]{6}{*}{ Household monthly income b } & 0 & $0.00+0.00$ & $0.000^{*}$ \\
\hline & $<$ RM 1000 & $25.67+7.87$ & \\
\hline & RM 1000-RM 2000 & $29.00+6.44$ & \\
\hline & RM 2000-RM 3000 & $25.57+6.12$ & \\
\hline & RM 3000-RM 4000 & $24.02+5.92$ & \\
\hline & $>\mathrm{RM} 4000$ & $21.54+5.75$ & \\
\hline \multirow[t]{5}{*}{ Number of children ${ }^{b}$} & 1 & $24.00+8.79$ & 0.687 \\
\hline & 2 & $23.25+6.33$ & \\
\hline & 3 & $23.00+5.33$ & \\
\hline & 4 & $22.96+6.85$ & \\
\hline & $\geq 5$ & $21.24+3.31$ & \\
\hline
\end{tabular}

Values were expressed as mean \pm standard deviation, * Indicates a significant difference at $p<0.05$, a Mann-Whitney test; ${ }^{\circ}$ Kruskal-Wallis test

\section{Parental practices on antibiotic use in children with URTIs}

Practices regarding antibiotic use in children with URTI varied (table 6). Only $13.6 \%$ of the parents did not always follow the doctors' advice regarding antibiotic use.
More than a quarter of the parents claimed they were not informed by the doctors as to whether or not the antibiotics were necessary for the treatment of URTIs. Very few parents (8.3\%) believed that their doctors prescribed antibiotics because of their request.

Table 6: Parental practices on the use of antibiotics in children for URTIs $(n=169)$

\begin{tabular}{|c|c|c|c|c|c|}
\hline \multirow[t]{2}{*}{ Q27-Q33 } & \multicolumn{5}{|c|}{ Number of respondents, $n(\%)$} \\
\hline & Never & Sometimes & Often & $\begin{array}{l}\text { Most of the } \\
\text { times }\end{array}$ & Always \\
\hline $\begin{array}{l}\text { Q27. How often do you ask your medical doctor as to whether or not the } \\
\text { prescription of antibiotics is necessary? }\end{array}$ & $\begin{array}{l}26 \\
(15.4)\end{array}$ & $65(38.5)$ & $\begin{array}{l}36 \\
(21.3)\end{array}$ & $16(9.5)$ & $\begin{array}{l}26 \\
(15.4)\end{array}$ \\
\hline Q28. How often does your medical doctor recommend antibiotics? & $7(4.1)$ & $93(55.0)$ & $\begin{array}{l}34 \\
(20.1)\end{array}$ & $24(14.2)$ & $11(6.5)$ \\
\hline $\begin{array}{l}\text { Q29. How often do you ask directly for your medical doctor to prescribe } \\
\text { antibiotics? }\end{array}$ & $\begin{array}{l}41 \\
(24.3)\end{array}$ & $65(38.5)$ & $\begin{array}{l}32 \\
(18.9)\end{array}$ & $17(10.1)$ & $14(8.3)$ \\
\hline $\begin{array}{l}\text { Q30. How often do you completely follow all the medical doctor's instructions and } \\
\text { advice? }\end{array}$ & $2(1.2)$ & $21(12.4)$ & $\begin{array}{l}43 \\
(25.4)\end{array}$ & $38(22.5)$ & $\begin{array}{l}65 \\
(38.5)\end{array}$ \\
\hline $\begin{array}{l}\text { Q31. How often do you insist on your medical doctor's prescribing antibiotics as a } \\
\text { precaution even if a diagnosis is not confirmed? }\end{array}$ & $\begin{array}{l}65 \\
(38.5)\end{array}$ & $38(22.5)$ & $\begin{array}{l}30 \\
(17.8)\end{array}$ & $16(9.5)$ & $\begin{array}{l}20 \\
(11.8)\end{array}$ \\
\hline $\begin{array}{l}\text { Q32. How often does your medical doctor inform you about your child's disease } \\
\text { and notify you whether it is necessary to receive antibiotics? }\end{array}$ & $8(4.7)$ & $39(23.1)$ & $\begin{array}{l}39 \\
(23.1)\end{array}$ & $36(21.3)$ & $\begin{array}{l}47 \\
(27.8)\end{array}$ \\
\hline $\begin{array}{l}\text { Q33. How often do you think that your medical doctor prescribes antibiotics only } \\
\text { because you asked him/her to? }\end{array}$ & $\begin{array}{l}98 \\
(58.0)\end{array}$ & $42(24.9)$ & $\begin{array}{l}15 \\
(8.9)\end{array}$ & $8(4.7)$ & $6(3.6)$ \\
\hline
\end{tabular}




\section{Relationship between knowledge and attitude scores}

There was a significant relationship between knowledge and attitude scores using the Spearman's rank-order correlation $(p<0.05)$. A moderate negative correlation was found between knowledge score and attitude score $\left(r_{s}=-0.498\right)$. This indicates that parents had positive attitudes despite having poor knowledge regarding the use of antibiotics in children with URTIs.

\section{DISCUSSION}

\section{Parental knowledge on antibiotic use in children with URTIs}

The overall parental knowledge on the use of antibiotics in children with URTIs was poor. Approximately half of the parents thought that antibiotics can be given to children with URTIs. More than half of the parents believed that children with flu-like symptoms recovered faster when antibiotics were given. URTI is an infection of viral origin, so it should not be treated with antibiotics [11]. The emergence of bacterial resistant strains may rapidly develop due to the inappropriate use of antibiotics [6, 12].

\section{Parental attitudes on antibiotic use in children with URTIs}

The present study found that parents had an overall positive attitude on the use of antibiotics in children with URTIs. Parents would not reuse any leftover antibiotics whenever their children show similar symptoms of URTIs. This positive attitude shown by parents can prevent the prevalence of antibiotic misuse that tends to occur in the society. Other than that, parents also agreed to be informed about judicious antibiotic use so that they can avoid from using antibiotics for the wrong indication. Unlike in Malaysia, in some developing countries, antibiotics are easily available even without prescriptions. Ecker et al. mentioned that since antibiotics do not require prescriptions to be accessed in Peru, parents tend to selfmedicate their children although the infection was of viral origin [13]. Bbosa et al. stated that the implication of antibiotics being easily available without a prescription is that it could lead to inappropriate use of antibiotics including the inability to complete full treatment, skipping doses as well as reuse of leftover antibiotics [14].

There were few aspects which reflected negative parental attitudes on the use of antibiotics in children seen in this study. More than a quarter of the parents still request for an antibiotic prescription from a doctor for their children's URTIs. It is sufficient for children who suffer from URTIs to take rest, have an adequate amount of fluid intake and use symptomatic treatment to help in the recovery process [15]. Parents had false beliefs that the infection would resolve faster by taking more drugs [16]. This situation leads to inappropriate antibiotic prescriptions by doctors and may lead to antibiotic misuse [7]. Parents also tended to seek help from a doctor if their child experienced flu-like symptoms such as a runny nose, cough and sore throat. These symptoms may also indicate an URTI which can usually recover on its own without antibiotics. McNulty et al. reported that most of the public still falsely believed that antibiotics are the first choice of drugs that can be used when they have a cough or cold and tend to visit a doctor to request for antibiotics [17].

\section{Parental practices on antibiotic use in children with URTIs}

Studies have reported that doctors prescribed antibiotics due to parents' requests $[18,19]$. However, a contradictory response was found in this study. Parents did not perceive that doctors would prescribe an antibiotic only because they had made the request. Parents would neither directly ask doctors to prescribe antibiotics nor insist that doctors prescribe antibiotics as a precaution even if the diagnosis has not been confirmed. Barden et al. stated that some parents, in fact, visit a doctor mainly to seek guidance, evaluation and reassurance about their children's condition and not primarily to ask for antibiotics prescription [7]. A study from Greece indicated that parents may consult a doctor to determine whether or not antibiotics were required for their child [10].

\section{Socio-demographic factors that influence parental knowledge} and attitudes

In the present research, it was found that parental knowledge and attitudes on the use of antibiotics for URTI were associated with gender, educational level and monthly income. A KAP study performed in Cyprus found that an increase in age and educational level could lead to better knowledge on antibiotic use in children with URTIs [20]. McNulty et al. also stated that better knowledge on the effectiveness of antibiotics could be observed in parents who had higher educational level [17]. Chan and Tang (2006) reported that parental attitude was found to be associated with educational level but not monthly income [8]. Parents with high educational level were reluctant to receive antibiotics for acute URTIs. Another study found that there was a lower expectation rate for antibiotics among younger and highly educated parents as compared to older and lower educated parents [21].

Lowman and Bowden (2012) reported that females have good attitude towards antibiotic use compared to males [22]. It may be due to mothers being more likely to take care of their sick children and tend to bring them to the hospital and get the doctor's advice as compared to fathers. Thus, this attitude can reduce the possibilities of parents giving their children antibiotics without a doctor's advice. However, Mitsi et al. found that females who were involved in raising their children had a negative attitude on this matter as they tended to self-medicate their children's disease which may also lead to the misuse of antibiotics [23].

\section{Relationship between knowledge and attitude scores}

The present study found that there was a moderate negative relationship between knowledge score and attitude score. As the knowledge score increased, the attitude score decreased. Contrary to our findings, Belongia et al. reported a positive linear relationship between knowledge and attitude, which indicated that poor knowledge led to bad practices. It was found that inappropriate use of antibiotics happened due to misconceptions on antibiotics among the respondents [24]. People may be reluctant to do something positive if they have a lack of understanding on a particular subject.

There are several limitations to this study. One of them is the small sample size of the respondents. Furthermore, since the study was conducted as convenience sampling within the allocated time, the respondents obtained may not represent the current actual population in Kuala Lumpur. The answers obtained from the respondents may be biased as the parents were allowed to complete the questionnaires at home. Thus, the answers might not reflect the actual knowledge, attitudes and practices of these parents regarding antibiotic use in children for URTIs.

\section{CONCLUSION}

This study provides an insight towards the parental KAPs on the use of antibiotics among children for URTIs. Overall, parents had poor knowledge but good attitudes on the use of antibiotics in children with URTIs. Gender, educational level and monthly income were significantly associated with knowledge and attitude scores. By identifying the weak points of parental KAPs, plans can be implemented to achieve good knowledge, attitudes and practices to curb the irrational use of antibiotics. This preliminary study can be used to develop strategies to enhance parental awareness on the importance of avoiding misuse of antibiotics in children.

\section{ACKNOWLEDGEMENT}

The authors would like to thank the parents for completing the questionnaire and the teachers at the kindergartens for their assistance.

\section{FUNDING}

No funding was received for this research

\section{CONFLICTS OF INTERESTS}

All authors have none to declare

\section{REFERENCES}

1. Couriel J. Assessment of the child with recurrent chest infections. Oxford J Br Med Bull 2002;61:115-32.

2. Hersh AL, Jackson MA, Hicks LA. American academy of paediatrics committee on infectious diseases. Principles of 
judicious antibiotic prescribing for upper respiratory tract infections in paediatrics. Pediatrics 2013;132:1146-54.

3. Thompson M, Vodicka TA, Blair PS, Buckley DI, Heneghan C, Hay $\mathrm{AD}$, et al. Duration of symptoms of respiratory tract infections in children: a systematic review. Br Med J 2013;347:1-19.

4. Van de Sande-Bruinsma N, Grundmann H, Verloo D, Tiemersma $\mathrm{E}$, Monen J, Goossens H, et al. The European antimicrobial resistance surveillance system and european surveillance of antimicrobial consumption project groups. Antimicrobial drug use and resistance in Europe. Emerging Infect Dis 2008; 14:1722-30.

5. Salonga MJC. Beliefs and practices of parents on the use of antibiotics for their children with upper respiratory tract infection. Pediatric Infectious Disease Soc Philippines J 2009;10:1-6.

6. Zoorob R, Sidani MA, Fremont RD, Kihlberg C. Antibiotic use in acute upper respiratory tract infections. Am Fam Physician 2012;86:817-22.

7. Barden LS, Dowell SF, Schwartz B, Lackey C. Current attitudes regarding use of antimicrobial agents: results from physicians' and parents' focus group discussion. Clin Pediatr 1998;37:665.

8. Chan GC, Tang SF. Parental knowledge, attitudes and antibiotic use for acute upper respiratory tract infection in children attending a primary health care clinic in Malaysia. Singapore Med J 2006;47:266-70.

9. Kindergarten Malaysia. Malaysia directory listing of kindergarten/nursery and daycare. Available from: http:// www.kindergartenmalaysia.com/en/Default.asp?Page86. [Last accessed on 27 Aug 2013]

10. Panagakou SG, Papaevangelou V, Chadjipanayis A, Syrogiannopoulos GA, Theodoridou M, Hadjichristodoulou CS. Risk factors of antibiotic misuse for upper respiratory tract infections in children: results from a cross-sectional knowledge-attitude-practice study in Greece. Int Scholarly Res Not 2012;1-8. http://dx.doi.org/10.5402/2012/685302

11. Dowell SF, Marcy SM, Phillips WR, Gerber MA, Schwartz B. Otitis media principles of judicious use of antimicrobial agents. Pediatrics 1998;101:165-71.

12. Friedman BC, Warf DS, Goldman R. Reducing inappropriate antibiotic use among children with influenza infection. Can Fam Physician 2011;57:42-4.

13. Ecker L, Ochoa TJ, Vargas M, Del Valle LJ, Ruiz J. Factors affecting caregivers' use of antibiotics available without a prescription in Peru. Pediatrics 2013;131:1771-9.

14. Bbosa GS, Wong G, Kyeqombe DB, Okeng JO. Effects of intervention measures on irrational antibiotics/antibacterial drug use in developing countries: a systematic review. Health 2014;6:171-87.

15. Bhanwra S. A study of the non-prescription usage of antibiotics in the upper respiratory tract infections in the urban population. J Pharmacol Pharmacother 2013;4:61-4.

16. Zolaly MA, Hanafi MI. Factors affecting antibiotics' prescription in general paediatric clinics. J Taibah University Med Sci 2011;6:33-41.

17. McNulty CAM, Boyle P, Nichols T, Clappison P, Davey P. The public's attitudes to and compliance with antibiotics. J Antimicrob Chemother 2007;60:63-8.

18. Smith RM, Stivers T, Elliott M, McDonald L, Heritage J. Online commentary during the physical examination: a communication tool for avoiding inappropriate antibiotic prescribing? Soc Sci Med 2003;56:313-20.

19. Mohan S, Dharamraj K, Dindial R, Mathur D, Parmasad V, Ramdhanie J, et al. Physician behaviour for antimicrobial prescribing for paediatric upper respiratory tract infections: a survey in general practice in Trinidad, West Indies. Ann Clin Microbiol Antimicrob 2004;3:11.

20. Rouusounides A, Papaevangelou V, Hadjipanayis A, Panagakou S, Theodoridou M, Syrogiannopoulos G, et al. Descriptive study on parents' knowledge, attitudes and practices on antibiotic use and misuse in children with upper respiratory tract infections in Cyprus. Int J Environ Res Public Health 2011;8:3246-62.

21. Vinker S, Ron A, Kitai E. The knowledge and expectations of parents about the role of antibiotic treatment in upper respiratory tract infection-a survey among parents attending the primary physician with their sick child. BMC Fam Pract 2003;4:20.

22. Lowman N, Bowden RG. Predictors of injudicious antibiotic seeking behaviour. Open Public Health J 2012;5:74-9.

23. Mitsi G, Jelastopulu E, Basiaris H, Skoutelis A, Gogos C. Patterns of antibiotic use among adults and parents in the community: a questionnaire-based survey in a Greek urban population. Int J Antimicrob Agents 2005;25:439-43.

24. Belongia EA, Naimi TS, Gale CM, Besser RE. Antibiotic use and upper respiratory infections: a survey of knowledge, attitudes, and experience in Wisconsin and Minnesota. Prev Med 2002;34:346-52.

\section{How to cite this article}

- Noraida Mohamed Shah, Mastura Abdul Rahim. Parental knowledge, attitudes and practices (KAPs) on the use of antibiotics in children for upper respiratory tract infections (URTIs). Int J Pharm Pharm Sci 2017;9(3):105-110. 